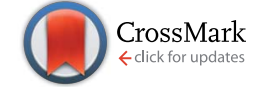

Cite this: RSC Adv., 2016, 6, 77075

Received 2nd June 2016

Accepted 25th July 2016

DOI: 10.1039/c6ra14334b

www.rsc.org/advances

\section{Comparison of antidiabetic potential of $(+)$ and $(-)$-hopeaphenol, a pair of enantiomers isolated from Ampelocissus indica (L.) and Vateria indica Linn., with respect to inhibition of digestive enzymes and induction of glucose uptake in L6 myotubes $\dagger$}

\author{
P. Sasikumar, ${ }^{a}$ B. Prabha, ${ }^{a}$ T. R. Reshmitha, ${ }^{\text {bc }}$ Sheeba Veluthoor, ${ }^{d}$ A. K. Pradeep, ${ }^{e}$ \\ K. R. Rohit, ${ }^{a}$ B. P. Dhanya, ${ }^{a b}$ V. V. Sivan, ${ }^{f}$ M. M. Jithin, ${ }^{f}$ N. Anil Kumar, ${ }^{f}$ I. G. Shibi, ${ }^{\star 0}$ \\ P. Nisha*bc and K. V. Radhakrishnan ${ }^{\star a b}$
}

The remarkable $\alpha$-glucosidase inhibition exhibited by the acetone extract of the rhizome of Ampelocissus indica (L.) and stem bark of Vateria indica Linn. ( $\left(\mathrm{C}_{50} 23.2\right.$ and $1.47 \mu \mathrm{g} \mathrm{mL}^{-1}$ ) encouraged us to isolate the phytochemicals from these plants. (+) and (-)-hopeaphenol (1) and (2) were isolated from $A$. indica (L.) and $V$. indica Linn. respectively. Compounds 1 and 2 displayed $I_{50}$ values of $21.21 \pm$ 0.987 and $9.47 \pm 0.967 \mu \mathrm{M}$ in an $\alpha$-glucosidase inhibitory assay. The effect of glucose uptake performed by 2-NBDG in L6 rat skeletal muscle cells using flow cytometry (BD FACS Aria II, USA) showed potent glucose uptake by (+) and (-)-hopeaphenol of $31 \%$ and $26.4 \%$, respectively. The data from an MTT cell viability assay revealed that the compounds are not toxic to the cells up to $200 \mu \mathrm{M}$. Molecular docking studies show that the compounds bind effectively to the active sites of the proteins $1 B V N, 3 A 4 A$ and $3 A J 7$, which supported the observed $\alpha$-glucosidase inhibition. The structures of these compounds were determined by the analysis of various spectroscopic data including HRMS-ESI, 2D NMR, CD spectroscopy, optical activity and were unequivocally established by single crystal X-ray crystallography. Herein we are reporting the phytochemicals from Ampelocissus indica (L.) and their antidiabetic activities for the first time.

\footnotetext{
${ }^{a}$ Organic Chemistry Section, National Institute for Interdisciplinary Science and Technology (CSIR), Trivandrum 695019, India. E-mail: radhu2005@gmail.com

${ }^{b}$ Academy of Scientific and Innovative Research (AcSIR), New Delhi 110001, India ${ }^{c}$ Agroprocessing and Natural Product Division, National Institute for Interdisciplinary Science and Technology (CSIR), Trivandrum 695019, India

${ }^{d}$ CoreValley's Herbal Technologies, 133-H, Mini Industrial Estate, Nallalam, Calicut673027, Kerala, India

${ }^{e}$ Department of Botany, Calicut University, Calicut, Kerala, India

${ }^{f}$ M. S. Swaminathan Research Foundation-Community Agrobiodiversity Centre (MSSRF-CAbC), Puthurvayal, Wayanad, Kerala, India

${ }^{g}$ Department of Chemistry, Sree Narayana College, Chempazhanthy, Thiruvananthapuram, Kerala, India

† Electronic supplementary information (ESI) available. CCDC 1035198 and 1061115. For ESI and crystallographic data in CIF or other electronic format see DOI: $10.1039 / \mathrm{c} 6 \mathrm{ra} 14334 \mathrm{~b}$
}

\section{Introduction}

Polyphenols, constituting oligomers of resveratrol ranging from dimers to octamers are found abundantly in plants belonging to the Vitaceae, Dipterocarpaceae, Leguminosae and Cyperaceae families. These naturally occurring polyphenols are common building blocks of a large number of complex natural products in terms of structure and stereochemistry. The biological activities such as anti-bacterial, ${ }^{1}$ anti-HIV, ${ }^{2}$ anti-inflammatory, ${ }^{3,4}$ and anti-proliferative property ${ }^{5}$ make resveratrol a potential drug candidate. The evaluation of the mechanism underlying the biological activities of resveratrol oligomers would provide a substantial clue in the development of new drug leads. Due to the pharmaceutical importance of resveratrols, the research group of Snyder and Nicolaou independently developed protocols for the total synthesis of resveratrols despite of their structural complexity. Among the resveratrol oligomers, the tetramer hopeaphenol shows a wide range of biological activities. ${ }^{6-8}$ In 2006, Merillon and co-workers isolated (+)-hopeaphenol from commercially available wine from North Africa. ${ }^{9}$ Recently Quinn et al. reported the isolation of (-)-hopeaphenol from Anisoptera species which inhibit the bacterial virulence type III secretion system (T3SS). ${ }^{10}$

It is evident from the literature that resveratrols are also accountable for antidiabetic activity and the recent works by Sharma et al. proved the efficacy of resveratrol as an effective therapeutic adjuvant for diabetes mellitus. ${ }^{11}$ Most of the available drugs used for curing type 2 diabetes causes serious side effects such as obesity, sexual and urologic complications. Kahn et al. reported a single mechanism to explain the link between obesity, insulin resistance and type 2 diabetes. ${ }^{12}$ The pervasiveness of type 2 diabetes is growing globally, and thus there is urgency for new antidiabetic drugs with less/no side effects. The plant derived antidiabetic drugs available in market reveals the potential of phytochemicals to regulate this metabolic disorder, 
compelling the search for new naturally inspired antidiabetic drug leads. ${ }^{13}$

In the limelight of these reports and due to our interest in the chemical profiling of the plants of ethnobotanical importance, first we selected the plant species Ampelocissus indica L. (AI). We have isolated $E$-resveratrol, $(\varepsilon)$-viniferin, $\beta$-sitosterolglucoside and pauciflorol along with the $(+)$-hopeaphenol. Inspired by the structural features of $(+)$-hopeaphenol, we decided to isolate and compare the resveratrol tetramers from another plant Vateria indica Linn. (VI) found in the Western Ghats region in Kerala, as a source of resveratrol oligomers. Among these plants the chemical constituents of the former one A. indica, to the best of our knowledge, is unknown to the phytochemical research community.

In this paper, antidiabetic activity of different extracts, the isolation and characterization of $(+)$ and $(-)$-hopeaphenol from $A$. indica (L.) and $V$. indica Linn. are described. Successively we studied the antidiabetic effect by digestive enzyme inhibition and glucose uptake in muscle cells. Different characterization techniques such as NMR, MS, CD, optical activity measurements and single crystal X-ray crystallography were utilised for the structural elucidation. While preparing the manuscript, Chang and Hou et al. reported the anti- $\alpha$-glucosidase and antidipeptidyl peptidase-IV activities of extracts and purified compounds from Vitis thunbergii var. taiwaniana. ${ }^{\mathbf{1 4}}$ The in vitro antidiabetic data for $(+)$ and (-)-hopeaphenol seems to be highly promising and warranted further evaluation.

\section{Materials and methods}

\subsection{Plant material}

The Rhizomes of Ampelocissus indica (L.) were collected from Calicut, Kerala and deposited in Calicut University herbarium (Voucher no. 6781). The bark of Vateria indica Linn. was collected from Wayanad and deposited in M. S. Swaminathan Research Foundation, Wayanad, Kerala (Voucher no. M.S.S.H.0763).

\subsection{General experimental procedure}

Optical activity was recorded on a Jasco P-1020 Polarimeter. NMR spectra were recorded at $25{ }^{\circ} \mathrm{C}$ on $500 \mathrm{MHz}$ BRUKER instrument. The ${ }^{1} \mathrm{H}$ and ${ }^{13} \mathrm{C}$ NMR chemical shifts were referenced to the tetramethylsilane (TMS) as standard. HRMS-ESI was recorded on a Thermo Scientific Exactive Column used: C18 (reverse phase column), CD spectrum was recorded on JASCO 810 Spectropolarimeter. UV spectrum was recorded UV 1800 Shimadzu UV Spectrophotometer. All solvents used for chromatography, UV, CD, MS were purchased from Merck (HPLC grade). For column chromatography, silica gel of different pore size 100-200, 230-400 were used. For $\alpha$-glucosidase and $\alpha$-amylase inhibition assay, acarbose was used as the standard and ascorbic acid as the standard for antiglycation assay. Glucose uptake assay was performed by 2-NBDG in L6 rat skeletal muscle cells using flow cytometry (BD FACS Aria II, USA). The effect of glucose uptake was compared with standard drug rosiglitazone, purchased from Merck.

\subsection{Biological screening}

2.3.1 Total phenolic content (TPC). TPC of the various solvent fractions were determined using Folin-Ciocalteu reagent and was expressed in mg GAE per $g$ of the dry extract. ${ }^{15}$ Absorbance was then read at $725 \mathrm{~nm}$ using a multiplate reader (Synergy, Biotek, USA).

2.3.2 DPPH radical scavenging activity. DPPH radical scavenging activity was estimated according to the method of BrandWilliams, Cuvelier and Berset. ${ }^{16}$ Various concentrations of the extracts were added to $1 \mathrm{~mL}$ of DPPH solution $(0.2 \mathrm{mM})$ and kept for incubation at room temperature in dark for about 30 minutes. A control and blank were also performed simultaneously. Gallic acid was used as the standard. The absorbance was read at $517 \mathrm{~nm}$ using a multiplate reader (Synergy 4 Biotek. USA). The percentage radical scavenging capacity was determined using the formula,

$$
\% \operatorname{RSA}=\left[\left(A_{0}-A_{\mathrm{S}}\right) / A_{0}\right] \times 100
$$

where $A_{0}$ is the absorbance of control and $A_{\mathrm{S}}$ is the absorbance of tested samples. A graph was plotted with concentration along $x$-axis and absorbance along $y$-axis and $\mathrm{IC}_{50}$ value was calculated and expressed in $\mu \mathrm{g} \mathrm{mL} \mathrm{mL}^{-1}$. $\mathrm{IC}_{50}$ value signifies the concentration of tested samples to scavenge $50 \%$ of the DPPH radical.

2.3.3 $\alpha$-Amylase inhibition assay. $\alpha$-Amylase inhibition activity was carried out in a microlitre plate according to Xiao et $a{ }^{1{ }^{17}}$ based on the starch-iodine test. Starch containing $\alpha$-amylase solution $\left(1 \mathrm{U} \mathrm{mL}^{-1}\right)$ and different concentrations of extracts/compounds were incubated at $50{ }^{\circ} \mathrm{C}$ for $30 \mathrm{~min}$. After incubation, the reaction was stopped with $1 \mathrm{M} \mathrm{HCl}$ and $100 \mu \mathrm{L}$ of iodine reagent was added to the reaction mixture. The absorbance was read at $580 \mathrm{~nm}$ on a microplate reader using Synergy 4 Biotek multiplate reader (USA). The known $\alpha$-amylase inhibitor, acarbose, was used a positive control. The percentage inhibition was calculated using following equation

$\%$ inhibition $=$

$$
\frac{\text { absorbance of control }- \text { absorbance of sample }}{\text { absorbance of control }} \times 100
$$

A graph was plotted with concentration along the $x$ axis and percentage inhibition along the $y$ axis to obtain the $\mathrm{IC}_{50}$ value.

2.3.4 $\alpha$-Glucosidase inhibition assay. $\alpha$-Glucosidase inhibitory activity was assayed as described by Disakwattana et al. ${ }^{18}$ Different concentrations of extracts/compounds containing $\alpha$-glucosidase solution $\left(1 \mathrm{U} \mathrm{mL}^{-1}\right)$ were vortexed and kept at room temperature for $5 \mathrm{~min}$, after incubation $250 \mu \mathrm{L}$ of PNPG was added and incubated at $37^{\circ} \mathrm{C}$ for $20 \mathrm{~min}$. The reaction was terminated by adding $500 \mu \mathrm{L}$ of $9.4 \mathrm{mM} \mathrm{Na}_{2} \mathrm{CO}_{3}$. Sample without compounds serves as control and commercially available acarbose were used as the standard. The absorbance was measured at $405 \mathrm{~nm}$ using multimode reader (Synergy 4 Biotek multiplate reader, USA). The $\alpha$-glucosidase inhibitory activity was expressed as the inhibition percentage and was calculated as follows:

$$
\begin{aligned}
& \% \text { inhibition }= \\
& \quad \frac{\text { absorbance of control }- \text { absorbance of sample }}{\text { absorbance of control }} \times 100
\end{aligned}
$$


A graph was plotted with concentration along the $x$ axis and percentage inhibition along the $y$ axis to obtain the $\mathrm{IC}_{50}$ value.

2.3.5 Anti glycation assay. It was performed according to the methods reported by Arom with slight modifications. ${ }^{19}$ About $500 \mu \mathrm{L}$ of albumin ( $1 \mathrm{mg} \mathrm{mL}{ }^{-1}$ final concentration) was incubated with $400 \mu \mathrm{L}$ of glucose $(500 \mathrm{mM})$ in the presence of $100 \mu \mathrm{L}$ of extracts/compounds at different concentrations, the reaction was allowed to proceed at $60{ }^{\circ} \mathrm{C}$ for $24 \mathrm{~h}$ and thereafter reaction was stopped by adding $10 \mu \mathrm{L}$ of $100 \%$ TCA. Then the mixture was kept at $4{ }^{\circ} \mathrm{C}$ for $10 \mathrm{~min}$ before subjected to centrifugation (Kuboto, Japan) at $10000 \times g$. The precipitate was redissolved in $500 \mu \mathrm{L}$ alkaline PBS (pH 10) and immediately quantified for the relative amount of glycated BSA based on fluorescence intensity at $370 \mathrm{~nm}$ (excitation) and $440 \mathrm{~nm}$ (emission) by Synergy 4 Biotek multiplate reader, USA. Ascorbic acid was used as the positive control.

2.3.6 Cell culture. L6 cell lines were obtained from NCCS, Pune, India. The cells were maintained in DMEM supplemented with $10 \%$ FBS and 1\% antibiotic/antimycotic solution, with $5 \%$ $\mathrm{CO}_{2}$ at $37{ }^{\circ} \mathrm{C}$. Differentiation of cells was induced by medium supplemented with $2 \%$ FCS. $^{20}$ Experimental assays were performed in differentiated myotubes.

2.3.7 Cell viability assay. The effect of compounds on the viability of L6 cells was determined by the MTT assay. ${ }^{21}$ L6 cells were seeded into 96 multi-well plates and cultured for $24 \mathrm{~h}$. Cells were treated with different concentrations of $(+)$ and (-)-hopeaphenol in a fresh medium containing 10\% FBS DMEM for $24 \mathrm{~h}$. After removing the medium, $100 \mu \mathrm{L}$ of MTT $\left(0.5 \mathrm{mg} \mathrm{mL}^{-1}\right)$ was added to each well and incubated for $4 \mathrm{~h}$. After removing the MTT medium, $200 \mu \mathrm{L}$ of DMSO was added to dissolve the formazan formed. After shaking, optical density (OD) at $570 \mathrm{~nm}$ was measured on a microplate reader by Synergy 4 Biotek multiplate reader, USA Untreated cells used as control.

$$
\% \text { cell viability }=\frac{\text { absorbance of sample }}{\text { absorbance of control }} \times 100
$$

2.3.8 Glucose uptake assay. Glucose uptake was performed in confluent and differentiated L6 myotubes were incubated for $24 \mathrm{~h}$ in medium (DMEM with low glucose) containing $100 \mu \mathrm{M}$ concentration of the $(+)$ and $(-)$-hopeaphenol. Compound free media and rosiglitazone $(100 \mathrm{nM})$ were used as negative and positive controls, respectively. After incubation, cells were washed twice with prewarmed $\left(37^{\circ} \mathrm{C}\right)$ phosphate buffer, $\mathrm{pH} 7.4$ and then incubated with 2 -NBDG in the same buffer for $30 \mathrm{~min}$ at $37{ }^{\circ} \mathrm{C}$. After $30 \mathrm{~min}$, cells were rinsed three times with phosphate buffer, $\mathrm{pH} 7.4\left(37^{\circ} \mathrm{C}\right)$ and cell lysate were used for flow cytometric analysis (BD FACS Aria II).

2.3.9 Molecular docking. The molecular docking studies of $(+)$ and (-)-hopeaphenol with various proteins 1BVN, 3A4A and 3AJ7 were carried out using MOE 2009.10. For identifying the active site of the proteins the default 'Site Finder' tool was used.

2.3.10 Single crystal X-ray analysis. Both compound 1 , (+)-hopeaphenol and compound 2, (-)-hopeaphenol were crystallized in $\mathrm{MeOH}$ : DCM $(60: 40)$ mixture at room temperature to give brown coloured crystals. Crystal structures were resolved with Bruker APEX-II CCD. These compounds belong to orthorhombic space group crystal system. (+)-Hopeaphenol cell length $a=11.2283(4), b=20.8486(7), c=24.0242(9), \alpha=\beta=\gamma$ $=90^{\circ}$. (-)-Hopeaphenol cell length $a=11.2315(2), b=$ 20.8456(5), $c=24.0263(6), \alpha=\beta=\gamma=90^{\circ}$ (see ESI $\dagger$ ). The cif crystallographic data for compound 1 and compound 2 was deposited at the Cambridge Crystallographic Data Centre, under the reference number CCDC 1035198 and 1061115 respectively. $\dagger$

\section{Results and discussion}

\subsection{Biological screening of different extracts of AI and VI}

The dried rhizome of AI and bark of VI were subjected to cold extraction with various solvents such as hexane, acetone, methanol and water. These extracts were analysed for its total phenolic content (TPC). The results showed that the acetone fraction of AI and VI are very rich in phenolic content (133.02 and $117.93 \mathrm{mg}$ GAE per $\mathrm{g}$ dry weight). DPPH radical scavenging activity is one of the most widely used method for screening the antioxidant activity of plant extract. Among different fractions of $\mathrm{AI}$ and VI, the highest DPPH radical scavenging activity was observed in acetone extract $\left(\mathrm{IC}_{50} 25.46\right.$ and $\left.25.59 \mu \mathrm{g} \mathrm{mL}^{-1}\right)$. The results from the study showed that the acetone fraction of $\mathrm{AI}$ and VI effectively inhibits $\alpha$-amylase enzyme $\left(\mathrm{IC}_{50} 100.44\right.$ and $17.13 \mu \mathrm{g} \mathrm{mL}^{-1}$ ), which is less active compared to the standard acarbose used $\left(\mathrm{IC}_{50} 5.69 \mu \mathrm{g} \mathrm{mL}{ }^{-1}\right)$ in this assay. All the fractions of AI and VI inhibit $\alpha$-glucosidase with acetone fraction having highest activity ( $\mathrm{IC}_{50} 23.2$ and $1.47 \mu \mathrm{g} \mathrm{mL}{ }^{-1}$ ) (Fig. 1), which is better than the standard acarbose used $\left(\mathrm{IC}_{50} 45.29 \mu \mathrm{g} \mathrm{mL}{ }^{-1}\right)$.

The higher level of glucose in the blood increases the glycation of proteins which leads to the formation of advanced glycated end products. These advanced glycated end products play key role in many diabetic complications. Therefore, there is an increasing demand for compounds which inhibits antiglycation. Compounds from plant sources having antioxidant activity possess antiglycation property also. ${ }^{19}$ The result from our study depict that the acetone fraction of AI possesses good antiglycation activity $\left(\mathrm{IC}_{50} 161.71 \mu \mathrm{g} \mathrm{mL}{ }^{-1}\right)$. But none of the VI extracts showed antiglycation activity. The standard ascorbic acid used in this assay is $\left(\mathrm{IC}_{50} 28.11 \mu \mathrm{g} \mathrm{mL}{ }^{-1}\right.$ ) (see ESI $\dagger$ ). The results are shown in Tables 1 and 2.

3.1.1 Isolation and structural comparison of $(+)$ and (-)-hopeaphenol. Being impressed by the promising
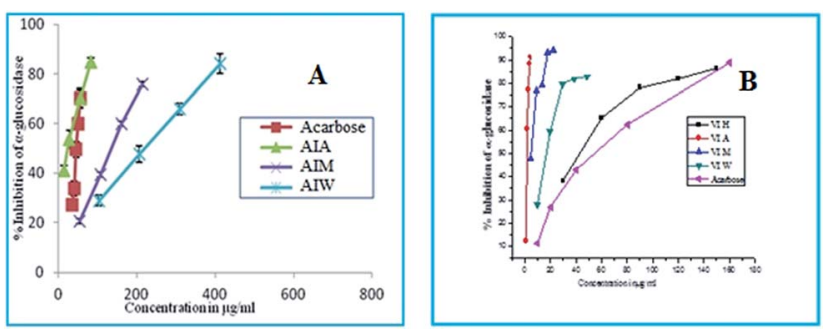

Fig. $1 \alpha$-Glucosidase inhibition activity of extracts of (A) Al and (B) VI. $(\mathrm{H})$ Hexane, (A) acetone, (M) methanol, (W) water acarbose serves as standard $\left(\mathrm{IC}_{50}\right.$ values, $\left.\mu \mathrm{g} \mathrm{mL}^{-1}\right)$. 
Table 1 Extract level biological screening of $\mathrm{Al}^{a}$

\begin{tabular}{|c|c|c|c|c|c|}
\hline Fractions & $\begin{array}{l}\text { TPC (mg GAE per } \\
\text { g dry weight) }\end{array}$ & $\begin{array}{l}\text { DPPH } \\
\left(\mathrm{IC}_{50^{-}} \mu \mathrm{g} \mathrm{mL}^{-1}\right)\end{array}$ & $\begin{array}{l}\alpha \text {-Amylase } \\
\left(\mathrm{IC}_{50}-\mu \mathrm{g} \mathrm{mL}{ }^{-1}\right)\end{array}$ & $\begin{array}{l}\alpha \text {-Glucosidase } \\
\left(\mathrm{IC}_{50}-\mu \mathrm{g} \mathrm{mL} \mathrm{m}^{-1}\right)\end{array}$ & $\begin{array}{l}\text { Antiglycation } \\
\left(\mathrm{IC}_{50}-\mu \mathrm{g} \mathrm{mL}^{-1}\right)\end{array}$ \\
\hline AI-H & $7.67 \pm 0.146$ & 1086.44 & NIL & NIL & NIL \\
\hline AI-M & $119.04 \pm 0.139$ & 41.15 & 5.86 & 133.29 & 200.66 \\
\hline AI-W & $67.63 \pm 0.522$ & 120.2 & 255.17 & 219.3 & 392.09 \\
\hline Standard & - & $\begin{array}{l}3.01 \\
\text { (Gallic acid) }\end{array}$ & $\begin{array}{l}5.69 \\
\text { (Acarbose) }\end{array}$ & $\begin{array}{l}45.29 \\
\text { (Acarbose) }\end{array}$ & $\begin{array}{l}28.11 \\
\text { (Ascorbic acid) }\end{array}$ \\
\hline
\end{tabular}

${ }^{a}(\mathrm{H})$ hexane, (A) acetone, (M) methanol and (W) water fractions of AI Ampelocissus indica (L.).

Table 2 Extract level biological screening of $\mathrm{VI}^{a}$

\begin{tabular}{|c|c|c|c|c|c|}
\hline Fractions & $\begin{array}{l}\text { TPC (mg GAE per } \\
\text { g dry weight) }\end{array}$ & $\begin{array}{l}\mathrm{DPPH} \\
\left(\mathrm{IC}_{50}-\mu \mathrm{g} \mathrm{mL}^{-1}\right)\end{array}$ & $\begin{array}{l}\alpha \text {-Amylase } \\
\left(\mathrm{IC}_{50}-\mu \mathrm{g} \mathrm{mL}{ }^{-1}\right)\end{array}$ & $\begin{array}{l}\alpha \text {-Glucosidase } \\
\left(\mathrm{IC}_{50}-\mu \mathrm{g} \mathrm{mL}^{-1}\right)\end{array}$ & $\begin{array}{l}\text { Antiglycation } \\
\left(\mathrm{IC}_{50}-\mu \mathrm{g} \mathrm{mL}^{-1}\right)\end{array}$ \\
\hline VI-H & $17.00 \pm 0.64$ & NIL & $68.09 \pm 0.822$ & $42.86 \pm 0.785$ & NIL \\
\hline VI-M & $26.27 \pm 1.00$ & $32.69 \pm 0.76$ & $40.37 \pm 0.38$ & $4.60 \pm 1.12$ & NIL \\
\hline VI-W & $37.34 \pm 0.035$ & $74.12 \pm 1.2$ & NIL & $16.54 \pm 0.77$ & NIL \\
\hline Standard & - & $\begin{array}{l}3.01 \\
\text { (Gallic acid) }\end{array}$ & $\begin{array}{l}5.65 \pm 0.23 \\
\text { (Acarbose) }\end{array}$ & $\begin{array}{l}45.73 \pm 0.92 \\
\text { (Acarbose) }\end{array}$ & $\begin{array}{l}28.11 \\
\text { (Ascorbic acid) }\end{array}$ \\
\hline
\end{tabular}

${ }^{a}(\mathrm{H})$ hexane, (A) acetone, (M) methanol and (W) water fractions of VI Vateria indica Linn.

antidiabetic activity of the acetone extract, we column chromatographed the acetone extract of $A$. indica (L.) rhizome (35 g) to afford 60 fractions (Fr. 1-Fr. 60). Fr. 25-48 eluted from the silica gel (100-200 mesh) column in $90 \%$ ethyl acetate in hexane were further purified by precipitation method by using chloroform and crystallized in $\mathrm{MeOH}$ : DCM at room temperature gave $500 \mathrm{mg}$ of compound 1 (+)-hopeaphenol as the marker compound. From the remaining fractions we have isolated $E$-resveratrol, $(\varepsilon)$-viniferin, ampelopsin, $\beta$-sitosterolglucoside and sitoindoside I. To resolve the structure and stereochemistry of hopeaphenol with a known sample, we extended our effort to isolate the similar molecule from the plant $V$. indica Linn. which is identified as a source of (-)-hopeaphenol. ${ }^{22-24}$ Even though bergenin was found as the marker compound in the acetone extract of $V$. indica Linn. Bark, we were able to isolate (-)-hopeaphenol from the crude acetone extract. About $70 \mathrm{~g}$ of the crude acetone extract were subjected to do the silica gel (100-200 mesh) column chromatography to afford 125 fractions (Fr. 1-Fr. 125). Fr. 80-93 eluted using 90\% ethyl acetate in hexane was further purified by precipitation method by using chloroform and crystallized in $\mathrm{MeOH}$ : DCM at room temperature gave $2 \mathrm{~g}$ of compound 2 . We could successfully isolate other phytochemicals including $E$-resveratrol, $(\varepsilon)$-viniferin, vaticaphenol A, $\beta$-sitosterolglucoside and sitoindoside I from the remaining fractions.

3.1.2 Compound 1. We were delighted to isolate (+)-hopeaphenol 1 (Fig. 3) from A. indica (L.). The compact tetrameric structure was elucidated following 1D and 2D NMR data analysis and also by comparison with literature report. ${ }^{25} \mathrm{HRMS}(\mathrm{ESI})$ showed a molecular ion peak at $m / z$ 907.2756 $[\mathrm{M}+\mathrm{H}]^{+}$which confirmed that the isolated compound was hopeaphenol. The absolute configuration was established on the basis of optical activity $[\alpha]_{\mathrm{D}}^{25}=+384^{\circ}(c a .0 .1 \mathrm{MeOH})$, which was in agreement with the reported value $[\alpha]_{\mathrm{D}}^{25}=+366^{\circ}(c a .0 .17 \mathrm{MeOH}) .{ }^{9}$ The UV spectrum of the compound in $\mathrm{CH}_{3} \mathrm{CN}$ showed an absorption maximum at 227 and $281 \mathrm{~nm}$ (Fig. 2a). Finally the structure and absolute configuration of (+)-hopeaphenol was unambiguously established by single crystal X-ray analysis (Fig. 4). To the best of our knowledge, we are reporting the chemical constituents from Ampelocissus indica and the single X-ray structure of (+)-hopeaphenol without any derivatization for the first time (Fig. 4a).

3.1.3 Compound 2. (-)-Hopeaphenol (Fig. 3) was isolated from the stem and bark of $V$. indica Linn. All the 1D and 2D NMR spectroscopic data were consistent with the literature values and finally confirmed by single crystal X-ray analysis (Fig. 4b). Optical activity $[\alpha]_{\mathrm{D}}^{25}=-369^{\circ}(c a .0 .1 \mathrm{MeOH})$ was also in good agreement with the reported values $[\alpha]_{\mathrm{D}}^{25}=-407^{\circ}(\mathrm{ca}$. 0.1 EtOH $){ }^{26}$ The structure and absolute configuration of (-)-hopeaphenol was determined in 1965 by Coggon et al. from
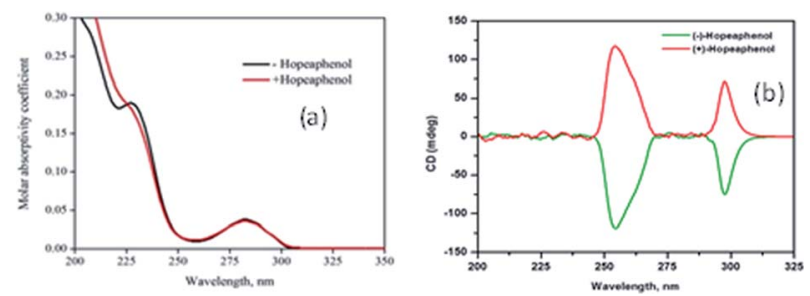

Fig. 2 (a) UV spectrum and (b) CD spectrum of (+) and (-)-hopeaphenol. 


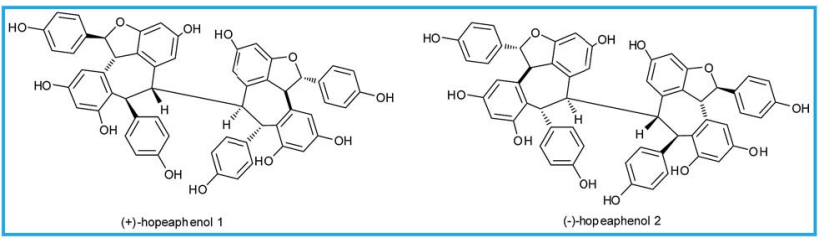

Fig. 3 Chemical structure of isolated compounds (+)-hopeaphenol (1), (-)-hopeaphenol (2).
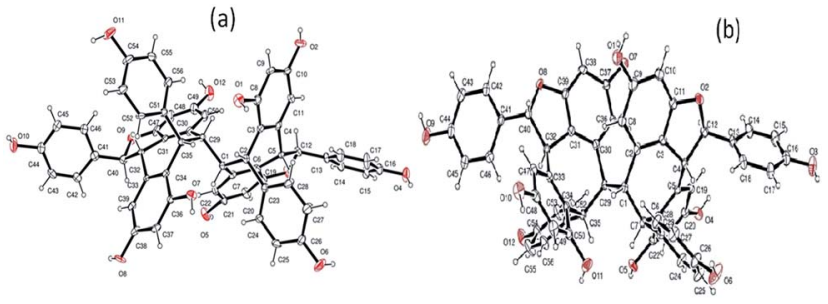

Fig. 4 ORTEP structure of (a) (+)-hopeaphenol and (-)-hopeaphenol.

the X-ray crystallographic studies of dibromodecamethyl derivatives. ${ }^{27}$ From the optical activity studies, CD data (Fig. 2b) and by comparison with literature values we came to know that both compound 1 from $A$. indica (L.) and compound 2 from $V$. indica Linn. are enantiomers.

\subsection{Biological screening of $(+)$ and $(-)$-hopeaphenol}

In order to showcase the biological activity of compounds, we investigated the hypoglycemic properties in terms of $\alpha$-amylase, $\alpha$-glucosidase, antiglycation and glucose uptake. The $\alpha$-amylase enzyme found in the pancreatic juice and saliva, catalyses the hydrolysis of 1,4-glucosidic linkages of starch, glycogen and various oligosaccharides into absorbable simpler sugars which are readily available for the intestinal absorption. Inhibitors of these enzymes delay the breakdown of carbohydrates in the small intestine, decreasing the absorption of glucose from starch and thereby diminishing the postprandial blood glucose excursion. ${ }^{28}$ The enzymes, $\alpha$-glucosidase and $\alpha$-amylases, are important therapeutic targets for the modulation of postprandial hyperglycemia which is the earliest metabolic abnormality to occur in type 2 diabetes mellitus. ${ }^{29}$ Unfortunately, the

Table $3 \quad I C_{50}$ values of (+) and (-)-hopeaphenol in $\alpha$-amylase inhibition, $\alpha$-glucosidase inhibition and antiglycation assay

\begin{tabular}{|c|c|c|c|c|}
\hline \multirow[b]{2}{*}{$\begin{array}{l}\text { Sr. } \\
\text { No }\end{array}$} & \multirow[b]{2}{*}{ Compounds } & \multicolumn{3}{|c|}{$\mathrm{IC}_{50}$ values $(\mu \mathrm{M} \pm \mathrm{SD})$} \\
\hline & & $\begin{array}{l}\alpha \text {-Amylase } \\
\text { Inhibition }\end{array}$ & $\begin{array}{l}\alpha \text {-Glucosidase } \\
\text { inhibition }\end{array}$ & Antiglycation \\
\hline 1 & (+)-Hopeaphenol & $68.75 \pm 0.876$ & $21.21 \pm 0.987$ & $81.9 \pm 1.176$ \\
\hline 2 & (-)-Hopeaphenol & $71.63 \pm 0.987$ & $9.47 \pm 0.967$ & $50.96 \pm 0.897$ \\
\hline 3 & Standard & $\begin{array}{l}8.5 \pm 0.898 \\
\text { (Acarbose) }\end{array}$ & $\begin{array}{l}81.3 \pm 1.10 \\
\text { (Acarbose) }\end{array}$ & $\begin{array}{l}158.23 \pm 0.718 \\
\text { (Ascorbic acid) }\end{array}$ \\
\hline
\end{tabular}

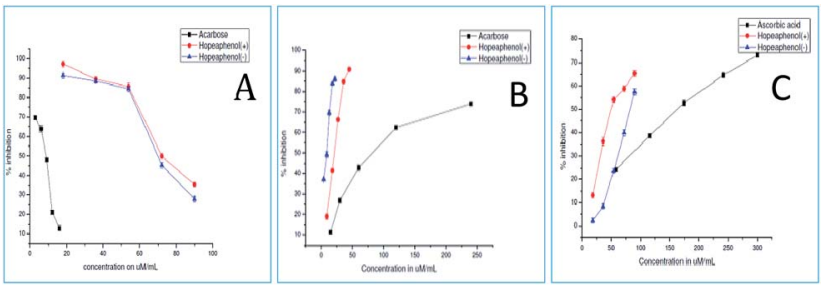

Fig. 5 (A) $\alpha$-Amylase (B) $\alpha$-glucosidase (C) antiglycation inhibitory activity of $(+)$ and $(-)$ hopeaphenol [acarbose and ascorbic acid serves as standard $\left(I C_{50}\right.$ values, $\left.\left.\mu \mathrm{M} \pm \mathrm{SD}\right)\right]$.

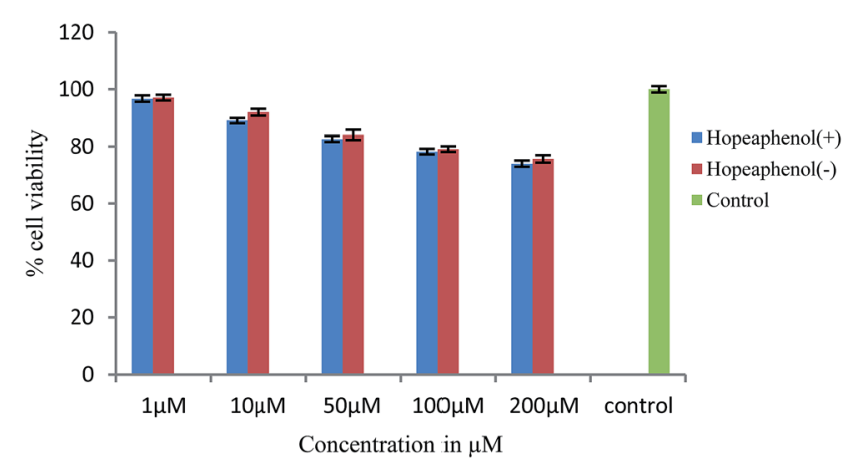

Fig. 6 Cell viability assay by MTT.

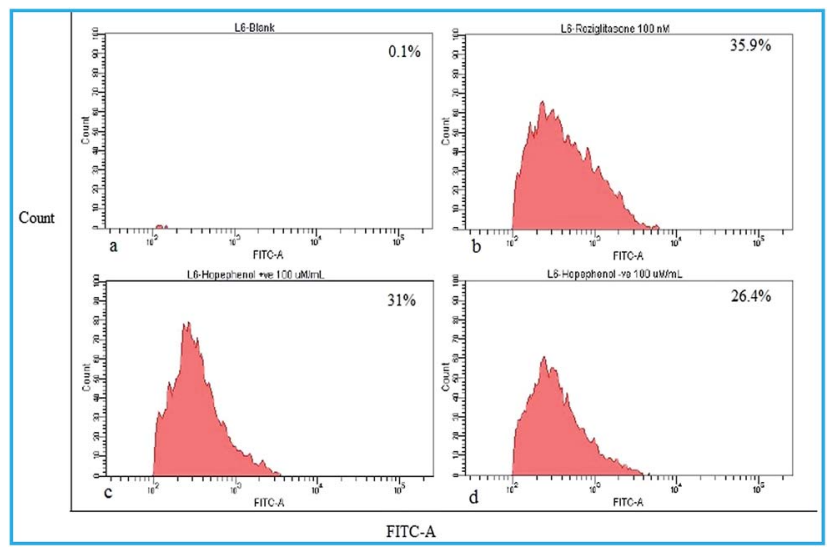

Fig. 7 Glucose transport in differentiated myoblast was assessed by the uptake of (a) control cells (b) rosiglitazone treated $(c) 100 \mu \mathrm{M}$ (+)-hopeaphenol treated cells (d) $100 \mu \mathrm{M}(-)$-hopeaphenol treated cells.

continuous administration of these synthetic drugs such as acarbose and miglitol, causes adverse side effects like diarrhoea, flatulence and hepatotoxicity. ${ }^{30}$ In the present scenario, natural products are explored with substantial interest for the management of diabetes owing to the side effects of currently available drugs. Therefore, $(+)$ and $(-)$-hopeaphenol were investigated for its anti diabetic potential.

The efficacy of enzymatic inhibition of compounds $(+)$ and $(-)$-hopeaphenol were determined from the $\mathrm{IC}_{50}$ values. The $\mathrm{IC}_{50}$ values represent the concentration of the compound 
Table 4 Molecular docking scores of (-)-hopeaphenol and $(+)$-hopeaphenol with various proteins $1 \mathrm{BVN}, 3 \mathrm{~A} 4 \mathrm{~A}$ and $3 \mathrm{AJ} 7$

\begin{tabular}{llll}
\hline & \multicolumn{2}{l}{ E score kcal mol} \\
\cline { 2 - 4 } Compounds & $1 \mathrm{BVN}$ & $3 \mathrm{~A} 4 \mathrm{~A}$ & $3 \mathrm{AJ} 7$ \\
\hline (-)-Hopeaphenol & -12.0251 & -6.4507 & -22.8589 \\
(+)-Hopeaphenol & -13.1447 & -15.3920 & -19.3913 \\
\hline
\end{tabular}

required to scavenge $50 \%$ of radicals in the reaction mixture. The compounds showed a concentration-dependent inhibition of both $\alpha$-glucosidase and $\alpha$-amylase enzymes. As can be seen from $\mathrm{IC}_{50}$ values (Table 3 ) the $\alpha$-glucosidase inhibitory activity of both the compounds were much higher than that of the standard acarbose indicating that the hopeaphenols can be promising $\alpha$-glucosidase inhibitor in diabetic management. $(+)$ and (-)-hopeaphenol exhibited amylase inhibition activity in a dose-dependent manner, however, the activity was less as compared to the standard acarbose (Fig. 5).

Advanced glycation end products (AGEs) are modifications of proteins or lipids that become non-enzymatically glycated and oxidized after contact with sugars, especially glucose during prolonged hyperglycemia. AGEs formed in vivo in hyperglycemic environments contributes to the pathophysiology of various diabetic complications. ${ }^{31}$ Thus, agents that inhibit the formation of advanced glycated end products are supposed to have therapeutic potential in patients with diabetes and age-related diseases. The results showed that both $(+)$ and $(-)$ hopeaphenol are potent antiglycation agents with $\mathrm{IC}_{50}$ values of 81.9 and $50.96 \mu \mathrm{M}$ respectively, compared to the standard ascorbic acid $\left(\mathrm{IC}_{50}-158.23 \mu \mathrm{M}\right)$. Additionally, the effect of hopeaphenols to enhance the glucose uptake in muscle cells were determined by 2-NBDG uptake assay. Prior to this, cytotoxicity of the compounds were determined by MTT assay in rat skeletal muscle cell lines, L6 myoblasts. ${ }^{21}$ The results indicated that the compounds $(+)$ and $(-)$-hopeaphenols are not toxic to cells up to $200 \mu \mathrm{M}$ concentration (Fig. 6). The sub-toxic concentration of hopeaphenols was calculated from the absorbance and is used for glucose uptake assay.

Effect of hopeaphenol on glucose uptake by cells was checked by glucose fluorescent analogue, 2-NBDG $(10 \mu \mathrm{M})$. Results indicated that (+)-hopeaphenol and (-)-hopeaphenol, at $100 \mu \mathrm{M}$ concentration, were able to enhance 2-NBDG uptake in $31 \%$ and $26.4 \%$ of cells respectively. The standard drug rosiglitazone $(100 \mathrm{nM})$ induced the uptake of glucose analogue 2-NBDG in $35.9 \%$ cells (Fig. 7). It is interesting to observe that both hopeaphenols significantly increase glucose uptake in cells suggesting the stimulatory activity for glucose uptake.

3.2.1 Docking interaction studies of the compounds with proteins. The molecular docking score of (-)-hopeaphenol and $(+)$-hopeaphenol with the protein $1 \mathrm{BVN}$ are -12.0251 and $-13.1447 \mathrm{kcal} \mathrm{mol}^{-1}$ respectively. Using LigPlot analysis the binding interactions of the ligands to the proteins were studied. No prominent interactions were observed for (-)-hopeaphenol

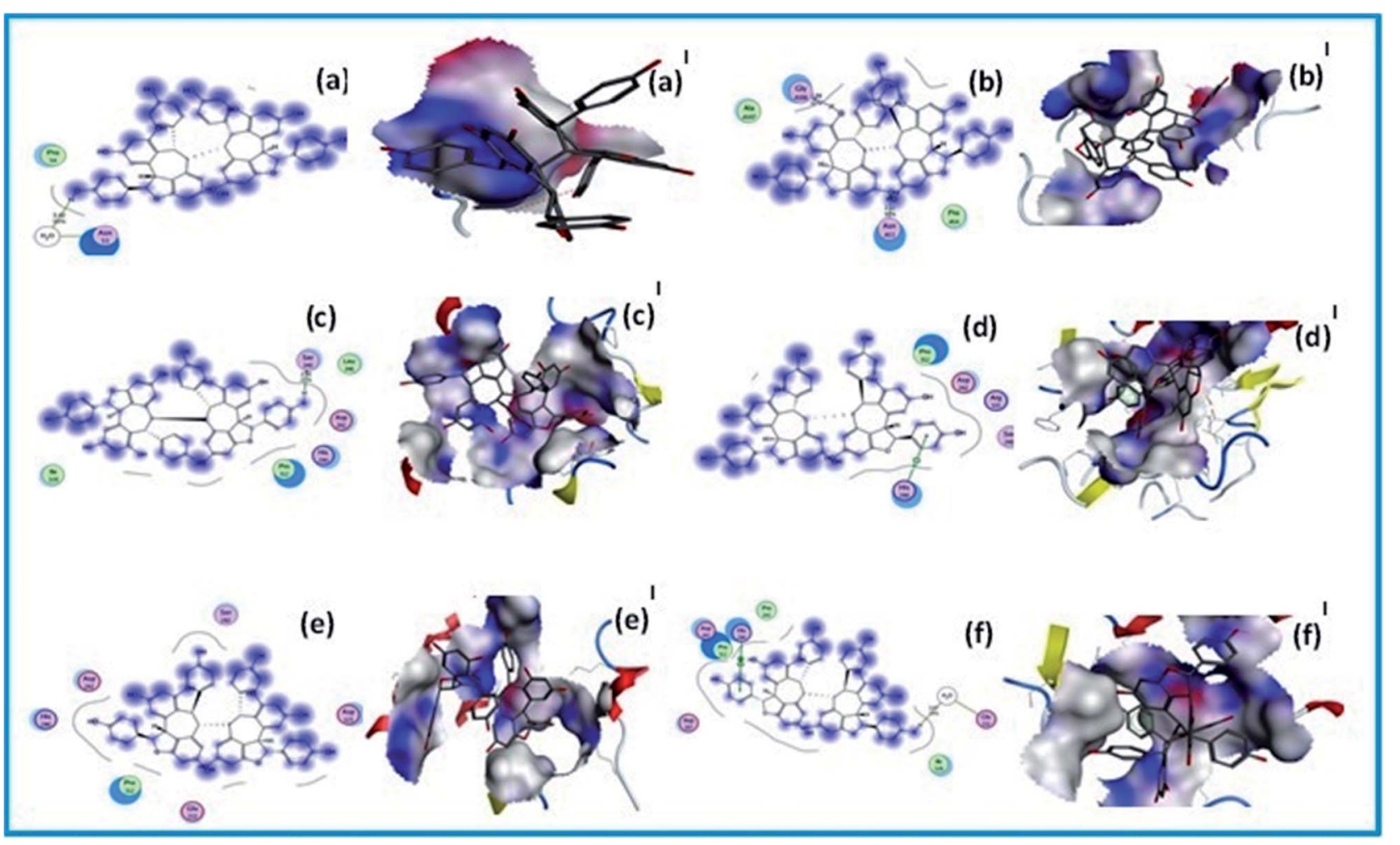

Fig. 8 Docking interaction studies of the compounds with proteins; $\left(a, a^{\prime}\right)$ and $\left(b, b^{\prime}\right)$ molecular docking studies of (-)-hopeaphenol and $(+)$-hopeaphenol with protein 1BVIt; $\left(c, c^{\prime}\right)$ and $\left(d, d^{\prime}\right)$ molecular docking studies of $(-)$-hopeaphenol and $(+)$-hopeaphenol with protein $3 \mathrm{~A} 4 \mathrm{~A}$ and; $\left(e, e^{\prime}\right)$ and $\left(f, f^{\prime}\right)$ molecular docking studies of $(-)$-hopeaphenol and $(+)$-hopeaphenol with protein $3 A J 7$ respectively. 
with this protein. But it shows an indirect hydrogen bonding interaction with a polar amino acid residue Asn53. Binding of (+)-hopeaphenol shows a backbone donor bonding interaction with a polar amino acid residue GlyA106 (2.04 А̊, 12\%).

The blue smudges that are drawn behind the groups represent the amount of solvent exposure. The molecular docking score of these compounds with the protein $3 \mathrm{~A} 4 \mathrm{~A}$ are -6.4507 and $-15.3920 \mathrm{kcal} \mathrm{mol}^{-1}$ respectively. The binding mode detected for the compound (-)-hopeaphenol gives a sidechain acceptor bonding interactions with a polar amino residue Ser240 (2.02 $\AA$, 25\%). Binding of (+)-hopeaphenol shows an arene-cation bonding interaction with basic amino acid residue His280. Comparatively very high molecular docking scores were observed for the compounds with the protein 3AJ7. There is no prominent interactions observed for (-)-hopeaphenol with this targeted protein. It showed a docking score of $-22.8589 \mathrm{kcal}$ $\mathrm{mol}^{-1}$ (Table 4). The binding mode detected for the compound $(+)$-hopeaphenol gives an arene-arene-cation bonding interactions with basic amino residue His280 (1.8 $\AA$, 66\%). And the dotted outline that is the proximity contour near this side of the ligand indicate the closeness of the groups present in that region of the ligand to the active site. It also shows a hydrogen bonding with both acidic amino acid residue Glu332 with a docking score of $-19.3913 \mathrm{kcal} \mathrm{mol}^{-1}$. The blue smudges that are drawn behind some of groups in certain cases represent the amount of solvent exposure (Fig. 8).

\section{Conclusion}

In conclusion, these in vitro results suggest that the compounds exert its antidiabetic effects through digestive enzyme inhibition and increased glucose uptake by the muscle cells. These multiple modes of action increase the interest in the use of $(+)$ and (-)-hopeaphenol as a therapeutic intervention for diabetes.

In order to find out how these two molecules interact with the target proteins, molecular docking studies were carried out. The result demonstrate that they bind effectively with the target proteins. In addition, the total phenolic content, DPPH radical scavenging activity, $\alpha$-amylase, $\alpha$-glucosidase, antiglycation inhibitory activity of different extracts of AI and VI has been carried out. From best of our knowledge, chemical constituents from $A$. indica (L.) and their exciting $\alpha$-glucosidase inhibition of compounds and extracts are reported for the first time. In vivo studies in the appropriate animal models are the next step in validating the antidiabetic potential of these isolated compounds.

\section{Abbreviations}

$\begin{array}{ll}\text { AI } & \text { Ampelocissus indica } \\ \text { VI } & \text { Vateria indica } \\ \text { HRMS- } & \text { High resolution mass spectrometry electron spray } \\ \text { ESI } & \text { ionization } \\ \text { PNPG } & p \text {-Nitrophenyl- } \alpha \text {-D-glucopyranoside } \\ \text { TCA } & \text { Trichloro acetic acid } \\ \text { 2-NBDG } & (2-(N-(7-N i t r o b e n z-2-o x a-1,3-\text { diazol-4-yl)amino)-2- } \\ & \text { deoxyglucose })\end{array}$

\section{Acknowledgements}

The authors thank UGC for research fellowship. The authors also thank the Council of Scientific and Industrial Research (CSIR), New Delhi, (12th FYP Project, NAPAHA-CSC-0130) for financial assistance. We thank Ms Soumini Mathew, Mr Saran P. Raveendran, Ms Viji S. and Ms Aathira S. for the NMR and HRMS analyses. Authors acknowledge Dr Jubi John, Dr Sarath Chand S., Mr Preethanuj P. and Mr Ajesh Vijayan for the help rendered during the preparation of the manuscript. Thanks are due to Dr K. M. Sureshan and Mr Alex Andrews of IISER Trivandrum, for single crystal X-ray analysis.

\section{Notes and references}

1 C. E. Zetterström, J. Hasselgren, O. Salin, R. A. Davis, R. J. Quinn, C. Sundin and M. Elofsson, The resveratrol tetramer (-)-hopeaphenol inhibits type III secretion in the Gram-negative pathogens Yersinia pseudotuberculosis and Pseudomonas aeruginosa, PLoS One, 2013, 8(12), 1-12.

2 J. R. Dai, Y. F. Hallock, J. H. Cardellina and M. R. Boyd, HIVinhibitory and cytotoxic oligostilbenes from the leaves of Hopea malibato, J. Nat. Prod., 1998, 61(3), 351-353.

3 A. Kukreja, N. Wadhwa and A. Tiwari, Therapeutic Role of Resveratrol and Piceatannol in Disease Prevention, J. Blood Disord. Transfus., 2014, 5(9), 1-6.

4 B. Annabi, S. L. Dufour, A. Vézina and R. Béliveau, Resveratrol Targeting of Carcinogen-Induced Brain Endothelial Cell Inflammation Biomarkers MMP-9 and COX-2 is Sirt1-Independent, Drug Target Insights, 2012, 6, $1-11$.

5 M. T. Empl, S. Macke, P. Winterhalter, C. Puff, S. Lapp, G. Stoica, W. Baumgärtner and P. Steinberg, The growth of the canine glioblastoma cell line D-GBM and the canine histiocytic sarcoma cell line DH82 is inhibited by the resveratrol oligomers hopeaphenol and r2-viniferin, Vet. Comp. Oncol., 2014, 12(2), 149-159.

6 S. A. Snyder, S. B. Thomas, A. C. Mayer and S. P. Breazzano, Total syntheses of hopeanol and hopeahainol a empowered by a chiral brønsted acid induced pinacol rearrangement, Angew. Chem., Int. Ed., 2012, 51(17), 4080-4084.

7 S. A. Snyder, A. L. Zografos and Y. Lin, Total synthesis of resveratrol-based natural products: a chemoselective solution, Angew. Chem., Int. Ed., 2007, 46(43), 8186-8191.

8 K. C. Nicolaou, T. Robert Wu, Q. Kang and D. Y. K. Chen, Total synthesis of hopeahainol A and hopeanol, Angew. Chem., Int. Ed., 2009, 48(19), 3440-3443.

9 H. A. Guebailia, K. Chira, T. Richard, T. Mabrouk, A. Furiga, X. Vitrac, J. P. Monti, J. C. Delaunay and J. M. Mérillon, Hopeaphenol: the first resveratrol tetramer in wines from North Africa, J. Agric. Food Chem., 2006, 54(25), 9559-9564.

10 R. A. Davis, K. D. Beattie, M. Xu Yang, X. S. Yin, H. Holla, P. C. Healy, M. Sykes, T. Shelper and V. M. Avery, Solving the Supply of Resveratrol Tetramers from Papua Guinean Rainforest Anisoptera Species That Inhibit Bacterial Type III Secretion Systems, J. Nat. Prod., 2014, 77(12), 2633-2640. 
11 S. Sharma, C. S Misra, S. Arumugam, S. Roy, V. Shah, J. A. Davis, R. K. Shirumalla and A. Ray, Antidiabetic activity of resveratrol, a known SIRT1 activator in a genetic model for type-2 diabetes, Phytother. Res., 2011, 25(1), 67-73.

12 S. E Kahn, R. L. Hull and K. M. Utzschneider, Mechanisms linking obesity to insulin resistance and type 2 diabetes, Nature, 2006, 444(7121), 840-846.

13 J. L. Evans, I. D. Goldfine, B. A. Maddux and G. M. Grodsky, Oxidative stress and stress-activated signaling pathways: a unifying hypothesis of type 2 diabetes, Endocr. Rev., 2002, 23(5), 599-622.

14 Y. S. Lin, C. R. Chen, W. H. Wu, C. L. Wen, C. I. Chang and W. C. Hou, Anti- $\alpha$-glucosidase and Anti-dipeptidyl Peptidase-IV Activities of Extracts and Purified Compounds from Vitis thunbergii var. taiwaniana, J. Agric. Food Chem., 2015, 63(28), 6393-6401.

15 V. L. Singleton and J. A. Rossy, Colorimetry of total phenolic with phosphomolybdic-phosphotungstic acid reagents, Am. J. Enol. Vitic., 1965, 16, 144-158.

16 W. Brand-Williams, M. E. Cuvelier and C. Berset, Use of a free radical method to evaluate antioxidant activity, $L W T$ Food Sci. Technol., 1995, 28(1), 25-30.

17 Z. Xiao, R. Storms and A. Tsang, Corrigendum to "A quantitative starch-iodine method for measuring alphaamylase and glucoamylase activities”, Anal. Biochem., 2006, 35, 146-148.

18 S. Adisakwattana, O. Lerdsuwankij, U. Poputtachai, A. Minipun and C. Suparpprom, Inhibitory Activity of Cinnamon Bark Species and their Combination Effect with Acarbose against Intestinal $\alpha$-glucosidase and Pancreatic $\alpha$ amylase, Plant Foods Hum. Nutr., 2011, 66(2), 143-148.

19 A. Jedsadayanmata, In Vitro Antiglycation Activity of Arbutin, Naresuan University Journal, 2005, 13(2), 35-41.

20 M. Tagami, Y. Nara, A. Kubota, T. Sunaga, H. Maezawa, H. Fujino and Y. Yamori, Morphological and functional differentiation of cultured vascular smooth-muscle cells, Cell Tissue Res., 1986, 245(2), 261-266.
21 T. Mosmann, Rapid colorimetric assay for cellular growth and survival: application to proliferation and cytotoxicity assays, J. Immunol. Methods, 1983, 65, 55-63.

22 T. Ito, T. Tanaka, M. Iinuma, K. I. Nakaya, Y. Takahashi, R. Sawa, H. Naganawa and V. Chelladurai, Two new oligostilbenes with dihydrobenzofuran from the stem bark of Vateria indica, Tetrahedron, 2003, 59(8), 1255-1264.

23 T. Ito, Y. Masuda, N. Abe, M. Oyama, R. Sawa, Y. Takahashi, V. Chelladurai and M. Iinuma, Chemical constituents in the leaves of Vateria indica, Chem. Pharm. Bull., 2010, 58(10), 1369-1378.

24 T. Ito, N. Abe, Y. Masuda, M. Nasu, M. Oyama, R. Sawa, Y. Takahashi and M. Iinuma, Two novel resveratrol derivatives from the leaves of Vateria indica, Helv. Chim. Acta, 2009, 92(1), 195-208.

25 F. Aisha, L. B. Din and W. A. Yaacob, Resveratrol tetramer of hopeaphenol isolated from Shorea johorensis (Dipterocarpaceae), AIP Conf. Proc., 2014, 302, 302-308.

26 P. Coggon, N. F. Janes, F. E. King, T. J. King, R. J. Molyneux, J. W. W. Morgan and K. Sellars, Hopeaphenol an Extractive of the Heartwood of Hopea odorata and Balinocarpus, $J$. Chem. Soc., 1965, 406-409.

27 P. Coggon, T. J. King and S. C. Wallwork, The structure of hopeaphenol, Chem. Commun., 1966, 13, 439.

28 Q. C. Chen, W. Y. Zhang, W. Jin, I. S. Lee, B. S. Min, H. J. Jung, M. Na, S. Lee and K. Bae, Flavonoids and isoflavonoids from sophorae flos improve glucose uptake in vitro, Planta Med., 2010, 76(1), 79-81.

$29 \mathrm{H}$. Lebovitz, $\alpha$-glucosidase inhibitors as agents in the treatment of diabetes, Diabetes/Metab. Rev., 1998, 6(2), 132-145.

30 D. M. Nathan, J. B. Buse, M. B. Davidson, E. Ferrannini, R. R. Holman, R. Sherwin and B. Zinman, Medical management of hyperglycemia in type 2 diabetes: a consensus algorithm for the initiation and adjustment of therapy, Diabetes Care, 2009, 32(1), 193-203.

31 A. Rojas and M. A. Morales, Advanced glycation and endothelial functions: a link towards vascular complications in diabetes, Life Sci., 2004, 76(7), 715-730. 